Journal of Economics and Behavioral Studies

Vol. 5, No. 9, pp. 603-611, Sep 2013 (ISSN: 2220-6140)

\title{
What Drives Private Saving in Botswana?
}

\author{
Naledi. C. Modisaatsone \\ Botswana Institute for Development Policy Analysis Gaborone, Botswana \\ nmodisaatsone@bidpa.bw
}

\begin{abstract}
This study examines the determinants of private saving in Botswana for the period covering 19942009. We use quarterly time series data to evaluate the magnitude and direction of the effects of key policy and non-policy variables on private saving. The variables examined are inflation, real interest rates, real gross national disposable income, degree of financial depth and dependency ratio. The dependency ratio is included in order to capture the effect of demographic influence on private savings. The stated determinants of savings are articulated in the context of the life cycle hypothesis. We investigate the short and long run behavior of the variables using an ARDL-ECM. The results suggest that there is a positive relationship between household income and their savings. The dependency ratio exerts a negative impact on private savings which supports the Lifecycle Hypothesis. The results also suggest that financial sector development has induced a positive impact on private savings in Botswana. Interest rates have a positive relationship with private savings; and, lastly, inflation has a negative relationship with private savings. Financial depth and real interest rates are the core policy instruments that the government can use to encourage savings in Botswana.
\end{abstract}

Keywords: Private savings, Autoregressive Distributed Lag Model, Error Correction Model

\section{Introduction}

While a poor country at independence in 1966, the discovery of diamonds, as well as fiscal discipline and sound economic management have enabled Botswana to maintain one of the world's highest economic growth rates leading the country into a middle income status. The country compares favorably with some, and appears to be doing better than some countries in terms of public savings. In 1994, national savings accounted for $31 \%$ of Botswana's GDP, the share had grown to about $41 \%$ in $2000 .{ }^{1}$ Although savings fell to around 30\% of GDP in 2002, the saving ratio increased to 38.5\% by 2008 (Bank of Botswana, 2009). Notwithstanding the favorable position of the country's national savings, there is a need to carefully examine private savings in Botswana. The disaggregation of savings in Botswana into public and private components indicates that almost 75 percent of total national savings is in the hands of the government while only 25 percent belongs to the private sector (Clarke, 1995). Botswana's significant economic success has resulted in the growth in the people's personal incomes over the years (Ahmed, 2007). A market brief by the AfDB (2011) showed that there has been a significant increase in Botswana's middle class. When analyzing the size of the middle class in total population, Botswana had $18.3 \%$ in 2008 and $29.3 \%$ middle class without floating class in 2011.It also shows that Botswana had 20\% in 2008 and $47.65 \%$ in 2011 of middle class with floating class $^{2}$. Consequently, an increase in the level of private savings that parallels the income level would be expected in Botswana, based on economic theory and the marginal propensity to save. The marginal propensity to save (MPS) indicates what the household sector does with extra income. The MPS indicates the portion of additional income that is used for saving. Because saving is the complement of consumption, the marginal propensity to save reflects key aspects about household consumption and saving activity.

Economic theory states that the more income a person earns, the more likely is an increase in their level of savings. The study will empirically examine whether or not this theory holds for Botswana. Elbadawi and Mwega (2000) conducted a study in which they observed that private savings in Botswana, on average, have

\footnotetext{
${ }^{1}$ The Central Statistics Office publication of 1993/94-2002/03 reported the national savings, which we then used to calculate savings as a ratio of GDP

${ }^{2}$ Floating class defined in the AfDB brief as the class that has per capita consumption levels of between $\$ 2$ - $\$ 4$ per day. Individuals at this level of consumption, which is only slightly above the developing-world poverty line of $\$ 2$ per person per day, remain largely vulnerable to slipping back into poverty in the event of some exogenous shock.
} 
lagged behind the Sub-Saharan Africa median rate by about 3.5\%. In their study Elbadawi and Mwega (2000) argued that Botswana needs to substantially enhance its private saving rates without necessarily reducing its current public savings. This is so because the mainstay of the economy is a non-renewable resource base. Inter-temporal welfare maximization suggests that optimal saving rates, consistent with maintenance of current consumption rates in the post-resource boom era, could be as high as 50\% of GDP. Therefore, enhanced private savings would be required for bridging inter-generational gaps and for maximizing economic welfare. In the literature of savings, the accumulation of savings is usually identified as one of the most important prerequisites for economic development (Aghveli et al., 1990). Private savings are reported to be very low in Botswana. The importance of a continuous and expanding flow of private savings for financing both private and public expenditure is well understood by the government of Botswana. Raising the rate of private savings is obvious, but the question is still through what policies and mechanisms can this be achieved. The objectives of this study are to examine the key determinants of private savings rates in Botswana from an empirical perspective based on quarterly time series data covering the period 1994-2009 and draw policy implications from the results. The study is structured as follows. Section 2 gives a background of the study. It discusses the policy environment, inflation, interest rates and financial sector development in Botswana. Section 3 reviews both the theoretical and empirical literature and section 4 specifies the empirical model. Section 5 reports the results, provides conclusions and policy implications

\section{Background of the Study}

Financial development: Botswana's formal financial sector has grown substantially since the Bank of Botswana's establishment in 1975 and the introduction of the Pula in 1976. In particular the sector experienced more rapid growth in the early 1990s following its (the sector) liberalization. Up to 1982(when the Bank of Credit and Commerce Botswana, came into the market), only two commercial banks, Standard Chattered and Barclays Bank operated in the country, both as branches of the British parent banks' South African subsidiaries. Other formal financial institutions operating in the country at the time included the Botswana Savings Bank, the Botswana Building Society, the National Development Bank, the Botswana Cooperative Bank and the Botswana Development Corporation. The latter listed institutions ${ }^{3}$ were all owned by the government and were established to fill in the gaps in the financial sector with respect to small savings, housing finance and long term agricultural and industrial funding. With significant financial liberalization in the early 1990s, the number of commercial banks has increased substantially over time, although commercial banks in Botswana are small by international standards. Currently, there are eight commercial banks, namely, Barclays Bank, Standard Chartered Bank, Stanbic Bank, First National Bank, Bank Gaborone, Bank of Baroda, Bank ABC and Capital Bank. There has been notable growth in financial instruments and improvements in the payments system. Total assets and liabilities of the commercial banks grew at an annual average rate of 19\% from P125.7 million in 1977 to P828.9 million in 1988 and then at an annual average rate of 19.1 from P1,081.9 million in 1989 to P17,758.4 million as at the end of 2005(BOB Annual Report, 2009). Despite the global financial crisis, the domestic banking sector performed well during 2008, with total assets and liabilities of commercial banks increasing by 21.4 percent to P43 billion (Bank of Botswana Annual Report, 2009)

The Non-Bank Financial Institutions Regulatory Authority (NBFIRA) is Botswana's regulator for pensions, insurances and capital markets. It was established in 2008, in the framework of the National Development Plan 10, which aims at positioning Botswana a financial services hub of Southern Africa. Setting up a modern and efficient regulator for Insurances, Pensions and Capital Market Participants is a critical step towards achieving the Government's economic diversification plans in the financial sector.The principal objective of NBFIRA is to regulate and supervise non-bank financial institutions so as to foster: (i) safety and soundness of non-bank financial institutions; (ii) highest standards of conduct of business by non-bank financial institutions; (iii) fairness, efficiency and orderliness of the non-bank financial sector; (iv) stability of the financial system, and; (v) reduction and deterrence of financial crime, (AfDB, 2010). Pension funds have become one of the most important segments of the financial system, following the creation of one fund, the Botswana Public Officers Pension Fund (BOPF). Pension Funds grew by 7\% in 2009, 3\% above GDP growth (4\%). The Pensions industry consists of 103 Funds with total assets of US $\$ 4.5$ million. It is worth noting that

\footnotetext{
${ }^{3}$ All the mentioned institutions are now parastatals
} 
the Public Service Pension Scheme is responsible for $80 \%$ of the Pensions Industry's assets. The asset management industry is roughly about $40 \%$ of all the assets of the various non-bank financial services industries and is estimated at around US\$ 4 billion. The Insurance industry is gaining prominence. It consists of the Life Insurance Industry also known as the Long Term Insurance business, the General Insurance industry also known as the Short Term Insurance Industry and the Medical Aid Funds Industry. The Life Insurance industry (Long term Insurance Industry) consists of some nine or so companies with total gross annual premiums of some US $\$ 200$ million with assets of some US $\$ 1.5$ billion. The General Insurance Industry (Short Term Insurance industry) consists of some eleven or so insurance companies with gross annual premiums of US $\$ 1$ billion with assets of some US $\$ 1.5$ billion (AfDB, 2010). The Botswana stock exchange had a market capitalization as at December 2009 of US $\$ 54$ billion. Capital market participants, regulated by NBIFIRA, include financial stock exchange, commodities exchanges, investment managers, CIUs, investment advisors, custodians, central securities depositories, securities dealers, trustees of CIUs and micro-lenders.

Real interest rates and Inflation in Botswana: In the face of rising inflation, monetary policy in Botswana remained tight during the given period (1994-2009). The rise in inflation in Botswana is influenced by a number of factors like higher inflation in Botswana's trading partner countries and the sharp increase in international oil prices. This factors lead to an increase in imported inflation. Domestic factors that affect inflation include Botswana's real GDP, broad money supply and the interest rate (Taye, 2013).The central bank has not been able to achieve the of 3-6\% inflation target. The real interest rates in Botswana are very low. The empirical evidence as well as the experience of East Asian countries suggests that pronounced positive real interest rates coupled with economic stability can lead to a significant rise in private savings.

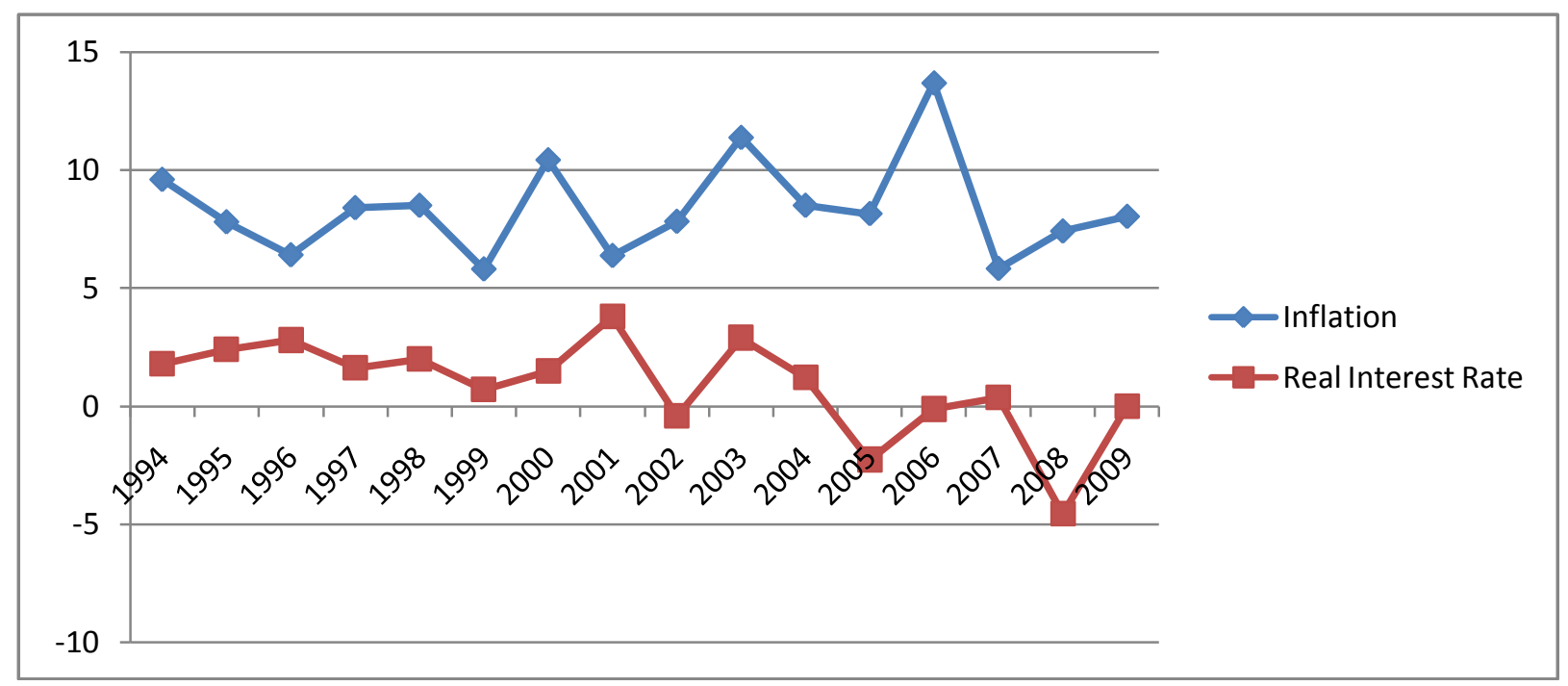

Data used: BFS and CSO Bulletins ${ }^{4}$

\section{Literature Review}

Theoretical Literature: The theory determines the choice of the variables to be used in the empirical specification. Both the Life Cycle Hypothesis (LCH) and Permanent Income Hypothesis (PIH) focus on the inter-temporal dimension of consumption. The two theories recognize that income is not necessarily all spent in the same period that it is earned. The LCH assumes that individuals plan to smooth consumption over their lifetime based on their expectations of their lifetime net wealth (Ozcan, Gunay \& Ertac, 2003). A principal implication of the LCH is that there are periods within their life span when savings are predictably low or negative. In particular, the LCH rests on the assumption that the earning potential of an individual grows throughout much of the person's working life, it is often rational both to borrow at a younger age and then save, first to pay off accumulated debts and then build up resources to fund consumption during retirement. The LCH is useful for analyzing the impact of demographic trends on savings patterns. The LCH suggest the

\footnotetext{
${ }^{4}$ The real interest rates used in this graph is the 88 day deposit rates from Bank Of Botswana BFS
} 
dependency ratio as one of the possible determinants of household savings (Ozcan, Gunay \& Ertac, 2003). The $\mathrm{PIH}$ postulates that households will attempt to smooth the pattern of their consumption over their lifetime. It thus looks at the impact of current income in the context of expected longer-term or permanent income. In this context, changes in current income would have different impacts on consumption, depending on whether they are viewed as permanent (such as moving to a new job, for example) or transitory(winning a prize in a raffle or lottery).The implications of the model are particularly important in assessing the role of macroeconomic policy in influencing the economy, since if the impact of, for example, changes in tax rates or real interest rates is viewed as being only temporary, it may not have much effect on consumption patterns. The PIH suggests macroeconomic variables like inflation, interest rates, gross national disposable income and financial development as possible determinants of household savings (Chowdhury, 2001).

Empirical literature: Ozcan, Gunay and Ertac (2003) investigated the effects of a number of policy and nonpolicy variables on private savings rates in Turkey. The income level had a positive impact on private saving rate; but the growth rate of income had no impact. From a policy perspective, the financial depth and development measure in Turkey suggested that countries with deeper financial systems will tend to have higher private saving rates. The precautionary motive for saving is supported by the findings that inflation captures the degree of macroeconomic volatility and had a positive impact on private saving in Turkey. Radipotsane (2007) conducted a study titled 'Determinants of Household Saving and Borrowing in Botswana' in which he looked at the form of household saving and borrowing in the country, drawing on a range of information, including comprehensive financial reporting, survey data and anecdotal evidence. Botswana households save in two types of financial institutions being formal and non-formal financial institutions. The study concluded that in the formal financial institutions, households save because the prevailing deposit rate is higher; hence they expect high returns on their savings. However, while theoretically it is expected that a rise in the real interest rate should lead to an increase in saving; this relationship was found to not be that strong in Botswana.

A study titled "The Impact of Financial Reform on Private Savings in Bangladesh" (Chowdhury, 2001) showed that the level of income, real interest rates and the share of agriculture in GDP had positive impacts on private savings. The results showed no support for the Ricardian Equivalence theorem. The financial reform index ${ }^{5}$ had a negative impact on private savings in Bangladesh. Hence, reforms that were initiated since the late 1980 's had actually reduced savings. Chowdhury and Baliamoune (2003) empirically analyzed the impact of financial reform on the level of private savings in Morocco. Time series models were estimated in order to evaluate the impact of various determinants of private savings - with special emphasis on financial reform. The results showed that per capita income, the dependency ratio and public savings had statistically significant impacts on private savings. The financial reform index, as measured by financial depth, had a positive impact on the level of private savings. This supported the view that financial reform had led to significant economic benefits, in particular through a more effective savings mobilization and a more efficient resource allocation process by reducing intermediation spreads, and enhancing financial deepening and access to credit. The results also suggested that economic policies that reform financial markets and enhance financial deepening could have significant impacts on the private savings rate. Hence, the importance of a stable macroeconomic environment, along with low fiscal deficits, a banking system with low non-performing loans, an effective regulatory and supervisory environment, and a contestable financial market cannot be underestimated.

\section{Methodology}

Model specification: The savings equation: The determinants of savings included in the model are as proposed by the LCH and PIH. The natural logarithm of the private saving rate(PS) is specified as a function of the natural logarithm of real gross national disposable income (RGNDI), real interest rate (deposit rate)(RIR),financial depth (FD),dependency ratio(DP) and inflation(INF) .The estimated model is specified as

\footnotetext{
${ }^{5}$ A rigorous measure of the financial reform index was developed in the study. The variable measures exogenous changes in the six dimensions of financial reform as described in Williamson and Mahar (1998): the elimination of credit controls, the deregulation of interest rates, and free entry into the financial services sector, government regulation of operations in financial institutions, privatization and liberalization of international capital flows.
} 
follows:

$$
\operatorname{Ln}(P S)=\alpha+\beta_{1} \operatorname{Ln}(R G N D I)+\beta_{2}(R I R)+\beta_{3} \operatorname{Ln}(D P)+\beta_{4} \operatorname{Ln}(F D)+\beta_{5}(I N F)+\varepsilon
$$

Methodological issues and data: There is a data challenge in Botswana just like in other developing countries. For this reasons, the results obtained should be interpreted with caution. The Central Statics Office (CSO) and Bank of Botswana do not publish data on Gross national disposable income (GNDI) and private savings. The available data is only for the period covering 1993/94-2002/03.Therefore some of the data had to be computed by the author. We followed the method used by CSO during the time period when they published such data. Masson, Bayoumi \& Samiei (1998) also constructed GNDI and Private Savings in the same way on their paper titled International evidence on the determinants of private savings. ${ }^{6} \mathrm{GNI}$ and current transfers from abroad for Botswana were obtained from the World Bank Website (World Development Indicators). Expenditure on capital goods and real interest rate were obtained from Bank of Botswana annual reports. Inflation and the dependency ratio were obtained from CSO publications.

Unit root test results: Gujarati (2004) argues that carrying out a regression analysis without the proper investigations into the data generating process can lead to spurious results. A major requirement when working with time series data is that the data should be stationary. In a stationary time series, the mean, variance and covariance do not change with time. We used the Augmented Dickey-Fuller (ADF) to determine if the data are stationary. When using the ADF technique, the data are stationary if the calculated ADF statistic is greater in absolute terms than the ADF critical statistic.

\section{Results}

Table 1: Unit root test

\begin{tabular}{|c|c|c|c|c|}
\hline \multirow[t]{2}{*}{$\begin{array}{c}\text { Variables } \\
\text { With Intercept }\end{array}$} & \multicolumn{2}{|c|}{$\begin{array}{l}\text { Unit Roots } \\
\text { Augmented Dickey -Fuller }\end{array}$} & \multirow[b]{2}{*}{0.05 Critical Values } & \multirow[t]{2}{*}{$\begin{array}{l}\text { Order of } \\
\text { Integration }\end{array}$} \\
\hline & Levels & First Difference & & \\
\hline LnPS & -1.24 & -9.08 & -2.910 & $\mathrm{I}(1)$ \\
\hline RIR & -2.13 & -6.07 & -2.90 & I(1) \\
\hline INFLA & -2.02 & -6.49 & -2.915 & $\mathrm{I}(1)$ \\
\hline LnFD & 1.34 & -8.88 & -2.910 & $\mathrm{I}(1)$ \\
\hline LnRGNDI & -2.39 & -4.48 & -2.91 & $\mathrm{I}(1)$ \\
\hline LnDP & -0.90 & -7.93 & -2.908 & $\mathrm{I}(1)$ \\
\hline
\end{tabular}

Note: The decision to reject the null hypothesis with trend \& with intercept and trend is based on ADF critical values at $5 \%$ which are given as -2.91 and -3.48 respectively

Looking at the unit root test results (Table 1), all the variables are only stationary in first difference. The computed values for the variables are greater than the critical values of the ADF test statistic in absolute terms at first difference and, therefore, the variables are stationary at first difference (I1).

Johansen Cointergration test: Unit root test results have shown that the variables are not stationary at levels and all are all stationary at first difference. We, therefore, test for cointegration among the variable using the Johansen Cointegration Test.

The Trace cointegration test tells us if there is cointegration and the number of cointegrated Vectors. From the results (Table 2), the Trace statistic rejects the null hypothesis of no cointegration at $5 \%$ level and shows that there is one cointegrating vector. This unveils the existence of a long run equilibrium relationship

${ }^{6} \mathrm{GDP}$ at current market prices +compensation of employees + Net entrepreneurial \& Property Income $=$ GNI.

GNDI=GNI + Current transfers from abroad, net.

GNDI - Final consumption expenditure = National Savings

National Savings-(Government Fiscal Surplus +Expenditure on capital goods)=Private Savings 
between private savings, real interest rates, inflation, dependency ratio and the real gross national disposable income.

Estimation: The auto-regressive distributed lag model: Equation (1) represents the long-run relationships among the variables of interest. The purpose of this study is, however, to examine both the short- and longrun relationships between private savings and its main determinants. In estimating equation (1), therefore, it is necessary to incorporate the short-run dynamics into our estimation procedure. This task can be done by specifying equation (1) in an error-correction modeling format. To that end, following the ARDL approach developed by Pesaran et al. (1999), equation (1) is reformulated as an error-correction modeling format:

$$
L n(P S)=\alpha+\beta_{1} \operatorname{Ln}(R G N D I)+\beta_{2}(R I R)+\beta_{3} \operatorname{Ln}(D P)+\beta_{4} \operatorname{Ln}(F D)+\beta_{5}(I N F)+\varepsilon
$$

Run an ECM regression of $\Delta \mathrm{y}$ on $\epsilon_{\mathrm{t}}, \Delta \mathrm{x}, \mathrm{p}-1$ lagged $\Delta \mathrm{y}^{\prime} \mathrm{s}$, and $\mathrm{q}-1$ lagged $\Delta \mathrm{x}^{\prime} \mathrm{s}$

$$
\Delta \mathrm{y}_{\mathrm{t}}=\propto \epsilon_{\mathrm{t}-1}+\sum_{-4}^{\mathrm{p}-1} \gamma_{\mathrm{j}} \Delta \mathrm{y}_{\mathrm{t}-\mathrm{j}}+\sum_{-\mathrm{q}}^{\mathrm{q}-1} \varphi_{\mathrm{j}} \Delta \mathrm{x}_{\mathrm{t}-\mathrm{j}}+\mathrm{u}_{\mathrm{t}}
$$

Table 2: Cointegration Rank Test (Trace)

\begin{tabular}{lllll}
\hline $\begin{array}{l}\text { Hypothesized } \\
\text { No. of CE(s) }\end{array}$ & Eigenvalue & $\begin{array}{l}\text { Trace } \\
\text { Statistic }\end{array}$ & $\begin{array}{l}\mathbf{0 . 0 5} \\
\text { Critical Value }\end{array}$ & Prob.** \\
\hline & & & & \\
None ${ }^{*}$ & 0.634999 & 130.3563 & 95.75366 & 0.0000 \\
At most 1 & 0.438768 & 68.87718 & 69.81889 & 0.0393 \\
At most 2 & 0.249145 & 33.64234 & 47.85613 & 0.5215 \\
At most 3 & 0.140021 & 16.16325 & 29.79707 & 0.7008 \\
At most 4 & 0.106546 & 6.961565 & 15.49471 & 0.5821 \\
At most 5 & 0.001463 & 0.089305 & 3.841466 & 0.7651 \\
& & & & \\
\hline
\end{tabular}

Trace test indicates 1 cointegrating eqn(s) at the 0.05 level

* denotes rejection of the hypothesis at the 0.05 level

**MacKinnon-Haug-Michelis (1999) p-values

Table 3: Results of the Error Correction Model (Short run dynamics)

\begin{tabular}{lllll} 
Variable & Coefficient & Std. Error & t-Statistic & Prob. \\
\hline $\mathrm{C}$ & 0.169432 & 0.083419 & 2.031096 & 0.0000 \\
$\Delta \mathrm{LnRGNDI}(-1)$ & 0.297399 & 0.071080 & 4.184003 & 0.0000 \\
$\Delta \mathrm{RIR}(-1)$ & 0.010123 & 0.004567 & 2.21655 & 0.0267 \\
$\Delta \mathrm{INF}(-1)$ & -0.008648 & 0.004150 & -2.083855 & 0.0131 \\
$\Delta \mathrm{LnFD}(-1)$ & 0.005743 & 0.002392 & 2.400919 & 0.0023 \\
$\Delta \mathrm{LnDP}(-1)$ & -0.000633 & 0.000549 & -1.153005 & 0.3774 \\
ECT-1 & -0.735756 & 0.135205 & -5.441795 & 0.0000 \\
& & & & \\
R-squared & 0.753211 & Mean dependent var & 0.027973 \\
Adjusted R-squared & 0.738580 & \multicolumn{2}{l}{ S.D. dependent var } & 0.200581 \\
S.E. of regression & 0.063184 & Akaike info criterion & -2.595150 \\
Sum squared resid & 0.227554 & Schwarz criterion & -2.391042 \\
Log likelihood & 87.74724 & Hannan-Quinn criter. & -2.514874 \\
Durbin-Watson stat & 2.277798 & &
\end{tabular}

The results show that the log of real gross national disposable income (LnRGNDI) is an important determinant of private savings in Botswana. The coefficient for LnRGNDI is positive and statistically significant. As theory suggests, the findings suggest that, as individuals incomes grow faster or as agents become richer, their savings increases. The results on the direction of the impact of disposable income on 
private savings are, therefore, consistent with both theory and those obtained in previous studies by, Nwachukwu \& Egwaikhide (2009) and Modigliani (1970).The results are also consistent with the cross country results of Modigliani (1993), Hussein \& Thirlwall (1999) and Loayza et al. (2000).The implication of these results is that any policy that encourages income growth in the long run will have a strong impact on private saving rates in Botswana. Another implication is that the high unemployment rate which results in low disposable income is a strong impediment in raising the saving rate in Botswana. The demographic variable exerts a negative impact on private savings. The coefficient on the dependency ratio has a negative sign and is statistically significant. The results suggests that there is a lot of dependence on the working class by the young and old family members which leaves them with very little to save. These results are also consistent with studies from other countries such as Nigeria by Nwachukwu and Egwaikhide (2009), where a negative relationship between private savings and the dependency ratio was established.

Financial Depth: The money supply to GDP ratio is positive and statistically significant. This finding is in line with our prediction that an increase in "Financial depth", proxied by the increase in M2 to GDP ratio, is likely to be very important in a country like Botswana, which has gone through a financial liberalization process. Financial liberalization includes interest rate liberalization, elimination of credit ceilings, easing of entry for foreign financial institutions, development of capital markets and enhanced prudential regulation and supervision. Liberalizing domestic financial markets, particularly done by strengthening the domestic banking sector, has improved efficiency of financial intermediation and hence investment, and positively contributed to private savings in the country. In order to achieve maximum benefits and promote private savings, therefore, financial deepening needs to be encouraged further. The (RIR) real interest rate variable is positive and statistically significant. The implication is that government should find an effective mechanism for increasing the abysmally low interest rate on bank deposits if the present effort to increase private saving rate is to achieve any measure of success. The estimation results show that inflation is statistically significant and has a negative relationship with private savings. The result here is different from other private savings studies most which found a positive relationship between private savings and inflation. For example, Nwachukwu and Egwaikhide (2009), found a positive relationship between private savings and inflation in Nigeria. We conclude that in Botswana increased macroeconomic uncertainty discourages people from saving.

\section{Conclusion}

Savings is an issue of fundamental importance in the economy and hence of interest for both academics and policy makers. While for an individual, saving is essentially a way to move resources over time (postpone consumption), for the economy as a whole the supply of savings represents an important source of financing investment. This paper examined the determinants of private savings in Botswana over the period 19942009. A model using variables that included the demographic factor (the dependency ratio) and economic factors (interest rates, gross national disposable income, inflation, financial deepening) was estimated. The results show that the prevailing negative real deposit rates are not motivating most households to save due to negative returns on postponed consumption. At the prevailing conditions, people are discouraged from saving since their savings get eroded by the combination of rising inflation and low deposit rates. From a policy point of view, financial depth variable has a positive relationship and is significant which suggest that the country should continue to invest in developing its financial systems in order to encourage private savings. Financial depth and real interest rates are the core policy instruments that the government can use to encourage savings in Botswana.

Acknowledgements: The author would like to extend gratitude to the Botswana Institute of Development Policy Analysis staff members for their valuable comments. Special thanks to Professor Taye, reviewers from Bank of Botswana and University of Botswana who gave very useful comments and guidance

\section{References}

African Development Bank. (2011). The Middle of the Pyramid: Dynamics of the Middle Class in Africa, Market Brief.

Aghveli, B., Boughton, J., Montiel, P., Villanueva, D. \& Woglom, G. (1990). The Role of National Saving in the World Economy. International Monetary Fund, Occasional Paper 67. 
Ahmed, A. (2007).Potential Impact of Financial Reforms on Private Savings in Botswana: An Empirical Analysis Using a VECM Approach. The Journal of Developing Areas, 41(1).

Bank of Botswana. (2009). Annual Report.

Chowdhury, A. (2001).The Impact of Financial Reform on Private Savings in Bangladesh. World Institute for Development Economics Research, Discussion Paper No.2001/78.

Chowdhury, A. \& Baliamoune, M. (2003). The long run behavior and short run dynamics of private savings in Morocco. Savings and Development, 27(2), 135-160

Clarke, L. C. (1995). The Financial Emergence of Southern Africa, Bank of Botswana, Gaborone.

Elbadawi, I. \& Mwega, F. (2000). Can Africa's Savings Collapse Be Reversed? The World Bank Economic Review, 14(3), 415-443.

Gujarati, D. (2004). Basic Econometrics, Fourth Edition

Hussein, K. \& Thirlwall, A. P. (1999). Explaining differences in the domestic savings ratio across countries: A panel data study. The Journal of Development Studies, Taylor and Francis Journals, 36(1), 31-52.

Loayza, N., Schmidt-Hebbel, K. \& Steven, L. (2000). What drives Savings across the World? Review of Economics and Statistics, 82(2), 165-181.

Masson, P. R., Bayoumi, T. \& Samiei, H. (1998). International Evidence on the Determinants of Private Saving. The World Bank Economic Review, 12(3), 483-501.

Modigliani, F. (1970). The life-cycle hypothesis and inter country differences in the saving ratio, in W. A. Eltis, M. FG. Scott, and J. N. Wolfe, eds., Induction, growth, and trade: essays in honor of Sir Roy Harrod, Oxford. Oxford University Press, 197-225.

Modigliani, F. (1993). Recent declines in the savings rate: a life-cycle perspective. In M. Baldassari, L. Paganetto, and E. Phelps (Eds.) World saving, prosperity and growth (pp. 249-286). London: Macmillan.

Nwachukwu, T. \& Egwaikhide, F. (2009). An Error Correction Model of the Determinants of Private Saving in Nigeria, Paper presented at the African Economic Society, Capetown, South Africa

Pesaran M. H., Shin Y. \& Smith R. P. (1999). Pooled Mean Group estimation of dynamic Heterogeneous panels. Journal of the American Statistical Association, 94, 621-34.

Ozcan, K., Gunay, A. \& Ertac, S. (2003). Determinants of Private Savings Behavior in Turkey. Applied Economics, $35,1405-1416$

Radipotsane, M. (2007). Determinants of Household Saving and Borrowing in Botswana.IFC Bulletin No 25

Taye, H. K. (2013). Inflation Dynamics in Botswana and Bank of Botswana's Medium-Term Objective Range. BIDPA Working Paper 36 


\section{Appendix}

Table 4: Long Run Model

\begin{tabular}{lllll}
\hline Variable & Coefficient & Std. Error & t-Statistic & Prob. \\
\hline C & & & & \\
LnRGNDI(-1) & 0.2467360 & 0.066509 & 3.7098137 & 0.0000 \\
INF(-1) & 0.0341085 & 0.015249 & 2.2367696 & 0.0000 \\
RIR(-1) & -0.0039314 & 0.001891 & -2.0790050 & 0.0469 \\
LnDP(-1) & 0.0042213 & 0.001286 & 3.2825038 & 0.0203 \\
LnFD(-1) & -0.0016925 & 0.000219 & -7.7283105 & 0.0000 \\
& 0.0052559 & 0.000731 & 7.1900136 & 0.0391 \\
R-squared & & & & \\
Adjusted R-squared & 0.740748 & Mean dependent var & 8.831116 \\
S.E. of regression & 0.116503 & S.D. dependent var & 0.550289 \\
Sum squared resid & 0.739598 & Akaike info criterion & -2.695809 \\
Log likelihood & 1.089093 & Hannarz criterion & -2.293414 \\
F-statistic & 223.9257 & Durbin-Watson criter. & 1.116075 \\
Prob(F-statistic) & 0.000000 & & & 2.012035 \\
\hline
\end{tabular}

Normality Tests

Table 5: Breusch-Godfrey Serial Correlation LM Test:

\begin{tabular}{llll}
\hline F-statistic & 25.52468 & Prob. F(2,55) & 0.0000 \\
Obs*R-squared & 30.29953 & Prob. Chi-Square(2) & 0.0000 \\
\hline
\end{tabular}

Table 6: Heteroskedasticity Test: ARCH

\begin{tabular}{llll}
\hline F-statistic & 2.273992 & Prob. F(2,58) & 0.1120 \\
Obs*R-squared & 4.435426 & Prob. Chi-Square(2) & 0.1089 \\
\hline
\end{tabular}

